\title{
Analysis of Administrative Region Proliferation Impact on Growth and Regional Development Equalization in Southeast Sulawesi of Indonesia
}

\author{
Muhammad Jusuf Abadi ${ }^{1}$, Amri Tanduklangi ${ }^{2}$, Hayat Yusuf ${ }^{3}$ \\ ${ }^{1}$ Department of Business and Economics, Universitas Halu Oleo Kendari 93232, Southeast Sulawesi, Indonesia \\ ${ }^{2}$ Magister of Management Program ,Universitas Halu Oleo Kendari 93232, Southeast Sulawesi, \\ ${ }^{3}$ Department of Business and Economics, Universitas Halu Oleo Kendari 93232, Southeast Sulawesi, Indonesia
}

\begin{abstract}
This study aims to analyse the impact of the proliferation of new autonomous regions on the growth and development distribution in Southeast Sulawesi Province of Indonesia. The study was conducted using secondary data available at the Central Bureau of Statistics and the regional working units. This study employs Input-Output analysis and Williamson Index. The results show that the splits of the region into several new autonomous regions increases economic growth, a relatively good index of the spread of the forward Linkage formbut with a slight increase of inequality of the regional development. In spite of the fact thatthe backward is relatively low but a squeezing of urban areas towards the hinterlandtakes place.In addition,the result also shows there has been no significant transformation of the economic structure of the agricultural sector to the industrial sector.
\end{abstract}

Keywords: Proliferation, Development inequality, forward linkage, backwardlinkage, Input-output analysis, Williamson index

\section{Introduction}

For more than 30 years of economic development, Indonesia had been quite well characterized by high economic growth in average at $7.2 \%$ per year $($ BPS $=$ Central Statistics Biro, 2000). In contrary,unequal development deteriorated with the Gini coefficient increased from 0.2659 becomes 0.401325 (DRN=Board of the National Research, 2014). The Gini coefficient is a measure of income inequality and regional disparity or between groups of people (Nozaki, 2014). When Approaching Gini coefficient value of one (1), meaning a very high income inequality. On the contrary, when the Gini coefficient is close to zero (0), it reflects low of income inequality, or in other words, people's income more evenly (Wikipedia:https://en.wikipedia.org/wiki/Gini_coefficient).

Low income and income inequality followed by development among regions will tend to cause social problems such as uncontrolled demonstrations, robbery, conflict between residents and inter-ethnic and even interreligions as happened in Aceh, Maluku, Poso in Central Sulawesi and Papua. The culmination of social discontent of Indonesian people had forced President Suharto to step down as President of the Republic of Indonesia in Jakarta from 20 to 21 May 1998. At that time the fall of the New Order regime was replaced by a reform regime lead by Baharuddin JusufHabibie as the third President of Indonesia.

In an attempt to overcome the above problems, the government and the Parliament made a Local Government Act 22 / 1999 and Act No.25 on Financial Balance between Central and Local Government (Kansil and Kansil (2001). The Act No.22 /1999 which is concerned with regional administration was later amended by Act No.32/2000. As a national development priority, decentralization and regional autonomy process has been made as a national development priority to focus on several aspects, namely clarification of power division among levels of governments, interregional cooperation, restructuring of regional government institution, improving the quality of personnel, fiscal capacity and restructuring of new autonomous regions (Bappenas $=$ the National Board of Planning and UNDP, 2008).

Implementation of theregional development paradigm or the top-down development approach (trickle-down effect) seems to be successful in the continents of Europe, India, South Korea and North America, especially in Canada. This approach had been implemented in Indonesia during the New Order era (Soeharto) from 1969 to 1998, but it did not work well as expected. Since reforms in 1999, the regional growth has been one of the national development policies in an attempt to overcome the failure of previous national development policies that implemented thetrickle-down effect approach.In spite of the fact,the top down approach had been able to boost economic growth, but the income and the development gap between regions was increasing. A previous study shows there has been a significant gap between the eastern part of Indonesia with the western region of Indonesia (JusufAbadi, 1998). The development of towns and villages since the New Order administration causes squeezing, a condition in which the rear stricken backwash effecthas been relatively small, while the city get great support in regional development. There has been increasingly rapid development of the city while rural development slowed downas it was the case in Southeast Sulawesi province (JusufAbadi, 1996). The condition like this also had occurred throughout Indonesian territory that has a high regional leak (Sondakh, 2005).

Based on the above conditions, theproliferation of administrative regions to develop new autonomous region has been a way out of developing equity.Before the 


\section{International Journal of Science and Research (IJSR) \\ ISSN (Online): 2319-7064}

Index Copernicus Value (2013): 6.14 | Impact Factor (2015): 6.391

reformation era,there were five (5) autonomous administrative regions in Southeast Sulawesi province, namelythe city of Kendari, districts of Buton, Konawe, Kolaka and Muna. Currently, the Province now has become 17 autonomous administrative regions, namely, Kendari, Baubau City, Konawe, South Konawe, North Konawe, Konawe Islands,Kolaka, North Kolaka, East Kolaka, Buton, Bombana, Wakatobi, Central Buton, South Buton, Muna, North Buton, andWest Muna.

\section{Methods}

The research was conducted in the area of Southeast Sulawesi using secondary data (documentation) obtained from the Central Statistics Agency (BPS) and the Work Unit (SKPD) of the province and theregencies/municipalities. The study uses Input-Ouput interregional analysis, nonsurvey method, and Williamson index.

The formula used in simplifying IRIO(inter regional inputoutput)tables is as follows:

$$
\text { (IA) } X=Y \text { or } X=(I A)^{-1 Y}
$$

where $\mathrm{I}$, is the identity matrix, $A$, is the matrix between regions, and $X$ is- $I$ region to move from $1,2, \ldots$..n region.

The Backward linkage or demand for input from the region I was calculated with the following formula:

$$
B_{j}=\frac{\sum_{i}^{n} x_{i j}}{x_{j}}=\sum_{i} A_{i j}
$$

Where, $B_{j}=$ backward linkage, $X_{i j}=$ number of output sector $I$, which was used as input to get the highest output of the sector $j$ of $X_{j}, X_{j}=j$ sector domestic output and $A_{i j}=$ input coefficient matrix elements.

Forward linkage was calculated with the following formula,

$$
F_{i}=\frac{\sum_{j} x_{i j}}{x_{i}}
$$

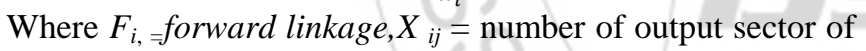
the region $\mathrm{I}$, which is used to generate the output sector $j X_{i}$ in region $j . X_{i}=$ total output demand throughout the region for the first sector-j.

$$
B L_{j}=\sum C_{i j}
$$

Where: $B L_{j}=$ indirect backward linkage, $C_{i j}=(I-A)^{-1}$

$$
F L_{i}=\sum C_{i j}
$$

Where: $F L_{i}=$ indirect forward linkage, $C_{i j}=(I-A)^{-1}$

$$
U_{j}=\frac{\sum_{i=1}^{n} C_{i j}}{\frac{i}{n} \sum_{i=1}^{n} \sum_{j=1}^{n} C_{i j}}
$$

Where: = backward power of dispersion, $C_{i j}=(I-$ $A-1$ and $n=$ number of vectors

$$
V_{i}=\frac{\sum_{j=1}^{n} C_{i j}}{\frac{i}{n} \sum_{j=1}^{n} \sum_{i=1}^{n} C_{i j}}
$$

Where: = forward power of dispersion, $C_{i j}=(I-A)^{-1}$ and $n=$ number of vectors

$$
P P_{s}=\sum A_{n+1 \cdot j} C_{i j}
$$

Where $A_{n+1^{\circ} j}:=$ coefficient input of the household sector (matrix rows household sector), = coefficient Leontief matrix or (households exogenous)

$$
\begin{array}{r}
P P_{I}=\frac{\sum A_{n+1 \cdot j} C_{i j}}{A_{n+1 \cdot j}} \\
\text { Or } \frac{P P_{s}}{A_{n+1 \cdot j}}
\end{array}
$$

$$
P P_{I I}=\sum A_{n+1 \cdot j} C_{i j}^{*}
$$

Where $C_{i j}^{*}=$ coefficient Leontief matrix or $(I-$ $\left.A^{*}\right)^{-1}$ (Households endogen)

$$
P T_{s}=\sum e_{n+1 \cdot j} C_{i j}
$$

Where $e_{n+1 \cdot j}:=$ physical labour coefficient (obtained from the equation of the production function)

$$
\begin{gathered}
P T_{I}=\frac{\sum e_{n+1 \cdot j} C_{i j}}{e_{n+1 \cdot j}} \\
\text { Or } \frac{P T_{S}}{e_{n+1 \cdot j}} \\
P T_{I I}=\frac{\sum e_{n+1 \cdot j} C^{*}{ }_{i j}}{e_{n+1 \cdot j}} \\
P O I=\sum_{i=1}^{m} C_{i}
\end{gathered}
$$

Where $C_{i}$ : $=$ coefficient matrix of inverse Leontief or $(I-A)^{-1}$ (households exogenous)

$$
P O I I=\sum C_{i j}^{*}
$$

Where $C_{i j}^{*}:=$ coefficient Leontief inverse matrix or $(I-$ $A *-1$.

Furthermore, to calculate inequitable development between regions, the formula of Williamson index is used as below:

$$
V_{w}=\frac{\sqrt{\sum_{i=1}^{n}\left(y_{i}-y\right)^{2}\left(f_{i} / n\right)}}{y} 0<V_{w}<1
$$

Where:

$Y i=G D P$ per capita in region $i$

$\mathrm{y}=$ GDP per capita on average across the region

$f i=$ Total population of region $i$

$\mathrm{n}=$ total population of the entire region.

Besides using Williamson index, we also employed Theil Index with the following formula.

$$
T_{d}=\sum_{i=1}^{n} \sum_{j=1}^{n}\left\{y_{i j} / Y\right\} \log \left[\frac{\left\{y_{i j} / Y\right\}}{\left\{{ }^{n_{i j}} / N\right\}}\right]
$$

Where:

$y i j=G D P$ percapita district in province $j$

$Y=$ Total GDP per capita across the province $\mathrm{j}$

$n=$ total population of the district $\mathrm{i}$ in province $\mathrm{j}$

$N=$ total population of all Regencies

$$
V_{w}=\varphi Y_{c}^{\delta} Y_{c}^{2}
$$

Where $V_{w}:=$ Index Williamson, $Y_{\mathrm{c}}=$ GDP per capita, while $\varphi$ and $\delta$ are regression coefficients. This equation was regressed through a double logarithmic with the following equation:

$$
\log V_{w}=\log \varphi+\delta \log Y_{c}+2 \log Y_{c}+\varepsilon
$$

Where: is the error factor (disturbance terms)

Determinants of inequality of development among regions as follows:

$$
V_{w}=\theta Y^{\beta}(L Q)^{\sigma} M^{\delta} I^{\eta}
$$

This equation was calculated with the method of regression after usinglogarithmic transformation.

Therefore, it was formulated as follows:

$$
\begin{array}{r}
\log V_{w}=\log \theta+\beta \log Y_{c}+\sigma \log (L Q)+\delta \log M+ \\
\eta \log I+\varepsilon
\end{array}
$$

Where $V_{w}$ is Williamson index, $L Q$ is the location quotient, $M$ is the migration (in percentage), $I$ is the investment allocation (in percentage) and $\theta, \beta, \sigma, \delta$, and $\eta$ is the regression coefficient and $\varepsilon$ is the error factor (disturbance factor).$s$ 


\section{International Journal of Science and Research (IJSR) \\ ISSN (Online): 2319-7064 \\ Index Copernicus Value (2013): 6.14 | Impact Factor (2015): 6.391}

\section{Results}

By using the formula of theIRIO table then the results obtained are as shown in table 1.

Table 1: Changes in income multiplier coefficients, linkages and multiplier output from 1996 to 2013.

\begin{tabular}{|c|c|c|c|c|c|c|}
\hline No & Coefficient & 1996 & 2000 & 2005 & 2010 & 2013 \\
\hline 1 & BWL & 0.9865 & 0.9992 & 0.9124 & 0.7632 & 0.7509 \\
\hline 2 & FWL & 1.5429 & 1.5785 & 1.6752 & 1.7111 & 1.7523 \\
\hline 3 & IBWL & 0.9897 & 1.2113 & 0.9875 & 1.2451 & 1.8754 \\
\hline 4 & IFWL & 2.1432 & 2.1567 & 2.4562 & 2.4997 & 2.3531 \\
\hline 5 & BPD & 0.6532 & 0.6672 & 0.7523 & 0.8763 & 0.7563 \\
\hline 6 & FPD & 2.3251 & 2.2665 & 2.1872 & 2.5545 & 2.6575 \\
\hline 7 & PPS & 2.0862 & 2.0998 & 2.5432 & 2.6231 & 2.6331 \\
\hline 8 & PP1 & 1.8752 & 1.8776 & 1.9879 & 2.021 & 2.6543 \\
\hline 9 & PP2 & 2.7657 & 2.8112 & 3.0032 & 3.2543 & 3.1891 \\
\hline
\end{tabular}

Source: Results of secondary data processing taken from BPS and Jusuf Abadi.

The table above shows the index of backward linkages, both direct coefficient and indirect coefficient concludes that the support of the municipalities as centres of growth on the back area is lower than that with the support of the rear area of the city or the centre of the growth is larger. Where in 2013, BWL at 0.7509 and 1.8754 while IBWL of FWL and IFWL respectively 1.7523 and 2.3531 .

This is in line with the index of the backward and forward deployment of which is equal to 0.7564 and 2.6575 respectively. In 2013 the highest sectors which have an adequate coefficient of income multiplier is financial institutions which areamounting to 2.9751 , the processing sector at 1.9858, the trade and services sectors in 2.9898, and the electricity sector amounted to 19925 .

While the sector has a highcoefficient of backward linkage is the financial sector, which is at 3.1925 , trade and services sector amounted to 2.1115, and the electricity and gas sectors in 3.555. Economic sectors which have a low coefficient of backward linkages is the agricultural sector in a broad sense withthe value of coefficient of 0.6785 . Then the sectors, which has a high coefficient of forward linkages are extensive agricultural sector in the epidermis of which is equal to 2.1121 , the mining and quarrying sector amounted to 3.1542 , services and trade sectors amounted to 2.1964 .

While the multiplier output since the division of the regions continues to experience a marked increase in the coefficient of the output multiple Simpler, type 1 and type 2 respectively are as follows 2.6331, 2.6543 and 3.1891. Economic growth of South East Sulawesi province and Indonesia can be seen in Table 2.

Table 2: Economic Growth in Southeast Sulawesi and Indonesia in 1996-2013

\begin{tabular}{|c|c|c|}
\hline Year & Southeast Sulawesi & Indonesia \\
\hline 1996 & 8.15 & 6.54 \\
\hline 2000 & 5.34 & 2.15 \\
\hline 2005 & 8.12 & 5.25 \\
\hline 2010 & 8.19 & 6.22 \\
\hline 2013 & 7.86 & 5.78 \\
\hline
\end{tabular}

Source; BPS Sultra from year to year.
The results of the analysis of the degree of inequality of development among regions in Southeast Sulawesi show a relatively low index, in other words regional development in Southeast Sulawesi is relatively evenly. By using the Williamson Index as previously used by Vidyatama 92013), the degree of inequality of development in Southeast Sulawesi which is obtained is as seen in Table 3.

Table 3: Inequality Development Index in Southeast Sulawesi from 1996 to 2013.

\begin{tabular}{|c|c|}
\hline Year & Inequality Index \\
\hline 1996 & 0.1132 \\
\hline 2000 & 0.1289 \\
\hline 2005 & 0.1222 \\
\hline 2010 & 0.1541 \\
\hline 2013 & 0.1599 \\
\hline
\end{tabular}

Source: Adapted from BPS Southeast Sulawesi

\section{Discussion}

The analysis above shows that the economic growth of Southeast Sulawesi since theproliferation of 5 regencies / municipalities into 17 regencies / municipalities is relatively good, because its growth is higher than that of the average growth of the national economy. Fluctuations in the growth rate due to the severe economic crisis happened in 1998. This also reflects Indonesia and other areas.

Building linkages between regions and between sectors are relatively good, although backward effect is lower than that of the forward effect. Conditions such as these tend to increase the gap or unequaldevelopment with regional growth of the centre back (hinterland). In turn, in the long term it will increase the inequality of development among regions.

The situation is supported by the fact that, although the level of inequitable development between regions is low or uneven, but the index of inequality between regions gradually becomes larger. In 1996 the index of inequality between the region is at 0.1132 , and in 2013 rose to 0.1599 .

Proliferation of administrative regions undergone in Southeast Sulawesi has encouraged increased revenue and income regions which is characterized by an increased income multiplier and the output multiplier. This is in line with (Keynes, in Bratakusumah, 2004) which says that in general within the newly opened area, economic growth will be higher, because a lot of factors of production which have not been used then become productive with lots of incoming investment, both public and private.

Proliferation of administrative region also has improved inter-sector development. The process of change in the economic structure in Southeast Sulawesi mainly comes from agriculture and services sectors. This is because the development of the downstream sector of superior products is not growing. This situation is due to the limited physical and economic infrastructure for the growth and development of the processing sector. The kind of infrastructure which is contributing to the most backward in the region is insufficient of electricity as a source of energy processing industry. 


\section{International Journal of Science and Research (IJSR) \\ ISSN (Online): 2319-7064}

Index Copernicus Value (2013): 6.14 | Impact Factor (2015): 6.391

This is not in line with the classical economic theory which posits that the economic transformation of the agricultural sector will happen prior to the new industry sector services sector, (Todaro, in Syafrisal 2013). This is because it is well understood that the development of the agricultural sector has been regarded as the central sector to more inclusive growth. As it is described by Kumari (2012), besides providing foods, the agriculture sector also provides employment opportunities to many people, raw material to industrial sectors and surpluses for national economic development. It is a well known fact that the Southeast Sulawesiprovince produces many industrial raw materials such as fish, cocoa, seaweed, nickel, forest products and agricultural products and horticultural crops, but are generally sold in the form of logs. In an effort to improve the linkages between regions and sectors (forward linkage) and the power of dispersion forward, the development of economic infrastructure such as electricity, transport (docks, roads, bridges and airports) must be increased with its capacity and its quality because a good infrastructure support is a mandatory to increase agriculture activities and productivities as well as to support the market for agricultural product.

\section{Conclusions}

The primary objective of this study was to examine the impact of the proliferation of new autonomous regions on the growth and development distribution in Southeast Sulawesi Province of Indonesia. This study found that the proliferation of the new autonomous region in Southeast Sulawesi province, which has boosted economic growth and equitable development among the regions remains good, however, the relative development of inequality index also has increased from year to year. As of 2013 the index of inequality is still around 1.1599 , which means the gap is still low or uneven. The research finding also suggests that the new regional autonomy divisions increased the relevance of development among regions, but the support of the growth centreof rear stricken is relatively low when compared to the support of the rear area to the growthcentre, or in other words, squeezing has occurred, so that in the long term this situation will increase inequality of development. Throughout this paper, we have argued that the development of the downstream sector has not well developed as a result of limited economic infrastructure supports, therefore the creation of added value is still relatively low which is potential to be developed to strengthen the foundation of the regional economy.

\section{References}

[1] Bappenas(the National Board of Planning) and UNDP. (2008). Evaluation of the Proliferation of Administrative Region in Indonesia $2001-2007$. Bappenas and UNDP: Jakarta, p. 1

[2] BPS (Central Biro of Statistics), Southeast Sulawesi.(2000). Southeast Sulawesi in Figures 2000, Kendari

[3] 2000, Indonesia in Figures 2000, Jakarta

[4] Kendari
[5] Kendari 2006, Southeast Sulawesi in Figures 2007,

[6] _ 2011, Southeast Sulawesi In Figures 2011, Kendari

[7] _ 2014, Southeast Sulawesi in Figures 2014, Kendari

[8] Bratakusumah, DS and Solihin D, (2004).Otonomi Pelenggaraan Pemerintahan Daerah. PT GramediaPustakaUtama: Jakarta

[9] DRN (Board of the National Research) (2014).Iptek untuk Indonesia Sejahtera, Berdaulat \& Bermartabat: Bunga Rampai Pemikiran Anggota Dewan Riset Nasional. DRN: Jakarta

[10] JusufAbadi, M. (1996).Analisis Keterkaitan Pembangunan antara wilayah Perkotaan dan perdesaan (Kasus Sulawesi Tenggara). Unpublished dissertation.UNHAS

[11] Jusuf Abadi, M. (2001). “Analisis Ketimpangan Pembangunan Ekonomi antara Kawasan Timur Indenesia dan Kawasan Barat Indonesia", Journal IPSUNM, Malang, 1 (35)

[12] Jusuf Abadi, M. andJusufAbadi, YusufAbadi, H (2014). Setengah Abad Sulawesi Tenggara Membangun. Rabbani Press (First edition): Jakarta Selatan

[13] Kansil, C.S.T danChristin S.T. Kansil (2001).Kitab Undang Undang Otonomi Daerah 1999 - 20001. PT PradnyaParamita: Jakarta

[14] Kumari, Resena and Rakesh Raman. (2012). "Disparity in Agriculture and Infrastructure Facility: Problems and Perspective". International Journal of Business \& Transformation. 5 (2), pp. 50 - 58

[15] Miller. ER, and Blair PD. (1985). Input Output Analysis. Foundations and Extensions. Englewood: New Jersey

[16] Nozaki, Kenji (2014). "Regional display and economic linkage in the Greater Mekong Sub-region". International Journal of Development Issues. 13(1): 59 $-70$

[17] Sondakh, L. (2012). Inequality of Development in Indonesia. Paper presented at the National Research Board (DRN) Plenary Meeting, Jakarta

[18] Syafrizal.(2013). Ekonomi Regional, teori dan Paraktis. Paraminta Offset: Padang.

[19] Todaro, Michle P and Smith, Stephan C. (2011).Economic Development. Erlangga: Jakarta

[20] Vidyatama, Yoga. (2013). "Regional Convergence and the role of neighbourhood effect in decentralized Indonesia". Bulletin of Indonesian Economic Studies, 49 (2): pp. 193 - 211

[21] Wikipedia. Gini Ratio. https://en.wikipedia.org/wiki/Gini_coefficient. Accessed 18 December 2014 